\title{
GENDER AND FISHERIES OF LAKE KAINJI, NIGERIA: A REVIEW
}

\author{
NWABEZE, G. O., IFEJIKA, P. I., TAFIDA, A. A., AYANDA, J.O., ERIE, A. P. * AND BELONWU, N. E.** \\ Socio Economics and Extension Services Division, National Institute for Freshwater Fisheries Research (NIFFR), New Bussa, \\ Niger State. \\ * Dept of Agricultural Economics \& Extension, Ambrose Alli University, Ekpoma. Edo State. \\ **Dept of Agricultural Science, College of Education, Agbor. Delta State
}

Copyright 2010, Fisheries Society of Nigeria.

This paper was prepared for presentation at the 25th Annual International Conference and Exhibition in Administrative Staff College of Nigeria (ASCON), Topo-Badagry, Lagos, Nigeria, 25th - 29th October, 2010

This paper was selected for presentation by an FISON Program Committee following review of information contained in an abstract submitted by the author(s). Contents of the paper, as presented, have not been reviewed by the Fisheries Society of Nigeria and are subject to correction by the author(s). The material, as presented does not necessarily reflect any position of the Fisheries Society of Nigeria, its officers, or members. Papers presented at FISON Society of Nigeria, its officers, or members. Papers presented at FISON Fish Fisheries Society of Nigeria. Electron review by Editorial Committees of the any part of this paper for commercial purposes without the written consent of the Fisheries Society of Nigeria is prohibited. Permission to reproduce in print is restricted to an abstract of not more than 300 words; illustrations may not be copied. The abstract must contain conspicuous acknowledgement of where and by whom the paper was presented. Write Librarian, Fisheries Society of Nigeria (FISON), P. O. Box 2607 Apapa, Lagos.

\section{ABSTRACT}

The paper examined gender and fisheries of Lake Kainji, Nigeria. The study highlights socio economic characteristics of women involved in Kainji Lake fisheries, important issues about gender and fisheries. It reveals that the categories of women in the Kainji Lake fisheries are in the middle age of 31 to 40 years with very low educational background. It also indicates that fish processing has been the most prominent activity of women in fisheries of Lake Kainji and constitute about 60 percent of the women. The study concludes that women play significant roles in all aspects of fisheries in Lake Kainji. Importantly, women's roles span reproduction and production.

Keywords: Women, Lake Kainji, Fisheries and Nigeria

\section{INTRODUCTION}

The fisheries sector is an important source of life and livelihood for millions of people around the world. As the world's largest wild food harvest, fish provides a vital source of protein as well as cash income for many families in the developing world (Yemaya, 2010; International Collective in Support of Fish workers (ICSF), 1997). It is further estimated that more than 120 million people throughout the world depend on fish for all or part of their incomes. In year 2000, FAO confirmed that about 35 million people world wide were directly engaged in fishing and fish farming (ICSF, 2009)

Globally, women of fishing communities play a central role in the fisheries and in maintaining the social fabric of their households and communities. In some regions, women have become important fish entrepreneurs. In the European Union, women control 39 per cent of the fish industry, administering and controlling significant sums of money and generating substantial returns for their household and community (Aguilar, 2002). As such, women earn, administer and control significant sums of money, financing a variety of fish-based enterprises and generating substantial returns for their household as well as the community. The important participation of women in natural resource-based livelihoods and resource management in the developing world (Nigeria inclusive) has long been acknowledged, but rarely been valued equally with the contribution of men. In fisheries, women have traditionally been occupied in pre and post-harvest processing of fish products and marketing the catch (Williams, 2006). However, they remain largely invisible, and the roles they play, largely undocumented. 
Women and men are engaged in complementary activities in fisheries. In most regions, the large boats used to fish large and deep waters bodies have male crews, while women manage smaller boats and canoes. Many more women engage in fishing with rudimentary equipment, wading along the shores collecting shellfish and seaweed contributing to the family income and nutrition security (FAO, 2004). In artisanal fishing communities, women are mainly responsible for performing the skilled and time-consuming tasks that take place on-shore, such as net making and mending, processing the catch and marketing it. In Nigeria, various studies revealed that women in fishing communities engage in long-hours daily activities in household chores, fishing, fish processing, packaging, preservation, storage, marketing of fish and other income generating non fisheries activities (Alamu and Mdaihli 1994; Alamu, 1992). These activities of women contribute to the socio-economic well being and sustenance of their households. It is against this background the study attempt to review the gender issues and fisheries of Lake Kainji, Nigeria.

\section{SOCIO ECONOMIC CHARACTERISTICS OF WOMEN INVOLVED IN KAINJI LAKE FISHERIES}

\section{Age distribution of the women}

A study of Wawu fishing community on the north eastern part of the lake basin indicated that of the 350 women engaged in the fisheries activities of the lake, $186(53.1 \%)$ of the women are between the ages of 31 to 40 years (Alamu and Mdaihli, 1994). While fewer $(n=17,4.9 \%)$ women in fisheries activities were less than 20 years of age (Fig. 1). This is supported by the work of Nwabeze et al. (2009) and Wara et al. on ten (10) fishing communities around the lake basin where women participation in fisheries is predominant. These categories of women are in the middle age bracket and are more favourably disposed to be innovative.

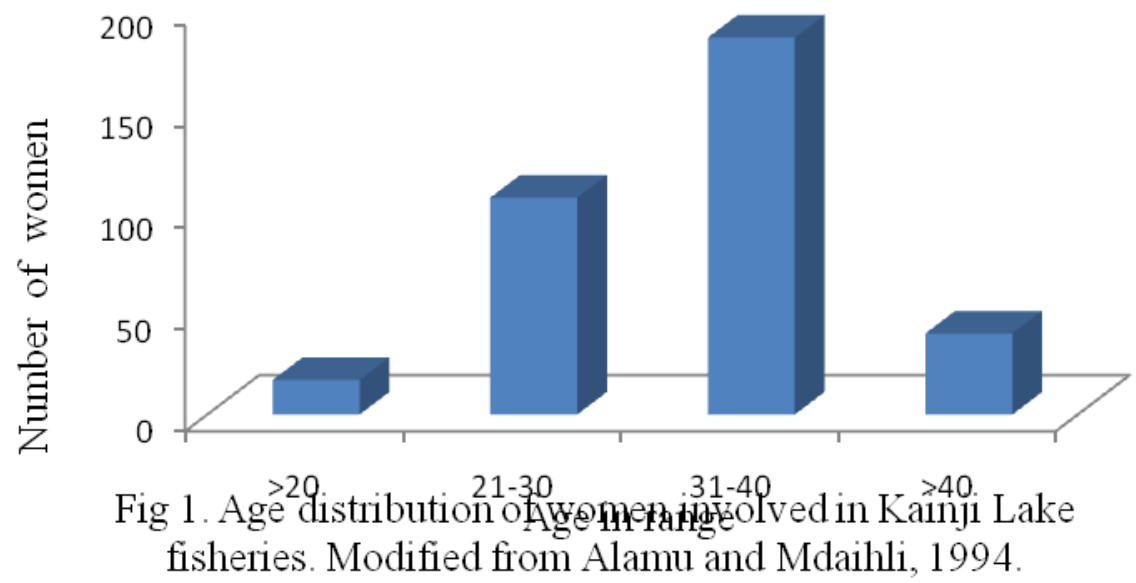

Educational Background of the Women 
According to Nwabeze et al. (2009), in study on socio economic variables influencing women participation in fisheries activities around Kainji Lake Basin found that $65 \%$ of the respondents had no formal education. About 32\% had Quranic education, while $3 \%$ had primary education. Alamu and Rettberg (1994) in study on fisherwomen of Kainji Lake confirmed that none of the 350 fisherwomen studied could read or write. Generally, the educational level of the women around Kainji Lake is very low irrespective of the marginal increase in primary education recorded in recent time. This affirmed the findings of Williams et al. (2006) and United Nation Development Programme (1995) that women from fisher households are depicted as illiterate.

\section{Ethnicity of the Women}

It was reported by Alamu and Mdaihli (1994) in socio-economic survey of women in artisanal fisheries of Lake Kainji that vast majority $(84.3 \%)$ of the women are of Hausa origin. Other minority ethnic groups in the area include Beriberi, Nupe, Zambarmawa, Kambari, Fulani, Bison and Youruba (Table 1). The ethnic diversity of the women in fisheries of the lake has insignificant effect on the culture, norms and values prevalent in the riparian fishing communities. Despite differences in ethnicity, the women share many characteristics which limit their development.

Table 1. Ethnicity Distribution of the Women

\begin{tabular}{lcc}
\hline Ethnicity & Frequency & Percentage \\
\hline Hausa & 295 & 84.3 \\
Beriberi & 21 & 6.0 \\
Nupe & 11 & 3.1 \\
Zambarmawa & 10 & 2.8 \\
Kambari & 5 & 1.4 \\
Fulani & 3 & 0.9 \\
Bison & 3 & 0.9 \\
Yoruba & 2 & 0.6 \\
Total & 350 & 100.0
\end{tabular}

Source: Modified from Alamu and Mdaihli, 1994.

\section{Marital Status of the Women}

It is established by Nwabeze et al. (2009) that majority (80\%) of women in fisheries studied in ten selected fishing communities within the Lake Basin is married. About $12 \%$ of them are single while $8 \%$ have divorced. This slightly varied from the study by Alamu and Maihli (1994) on 350 women in artisanal fisheries of Lake Kainji that $98.0 \%$ of the women are married. However, the dominance of married households implies that the women are likely to be proactive in fisheries because of its immense benefits in ensuring food security, income generation and reduced vulnerability within the household (Nwabeze et al., 2009).
Gender Aspects of Kainji Lake Fisheries

Available data does not capture the multidimensional nature of work undertaken by women of fishing communities. In general, while the exact nature of women's work differs by culture and region and between rural and urban areas, the common factor is that it is rarely seen as productive. It has low social value and is normally seen as an extension of the domestic space. Little value is attached to the domestic and community tasks performed by women. In fishing Women engage in a wide range of activities in the fisheries and in fishing communities all around the world. In many 
countries, it is mostly rural women who are engaged in inland fishing. In Africa, they fish the rivers and ponds (FAO, 2004). In Kainji Lake Basin, Nigeria, women play a significant role in the development of the fisheries resources of the Lake (Nwabeze et al, 2009).

Studies on fisherwomen of Kainji Lake by Rettberg et al (1994) confirmed that women engage in fishing activities and contribute to the total fish catch of the Lake. He reported that $72 \%$ of the women studied had fishing background while $28 \%$ do not have prior knowledge of fishing. The later considered fishing on economic reasons. The fishing women were characterized as active and passive fishers. The active fishing women acquire personal fishing equipment and fish directly on their own or as assistant. They are characterized as spouse of fishers and non fishers. Passive fishing women possess fishing gears, which are either used by husband or children to fish for them. It was reported that there were no fixed financial arrangement the children assistance as it constitutes part of family labour necessary for the survival of the fishers' household.

Rettberg et al. (1994) established that majority (95\%) of the fishing women fish using mainly gillnets canoes and paddles in shallow waters. Other fishing gears possessed by the women include castnets, fish traps, longlines and locally made gillnets. The mean number of gillnets per women 24.7 and average mesh size is 2.2 inches. This will have effect on the size and species of fish by the fishing women. It was further indicated that about $(50.5 \%)$ of the women fish on and off shore while $37.7 \%$ fish only offshore. About $83.2 \%$ fish everyday between 1 and 4 hours daily. This was considered a temporary fishing intensity. This is dependent on the prevailing livelihood activities within a particular time.
Fish processing has been the most prominent activity of women in fisheries of Lake Kainji and constitute about 60 percent of the women (Nwabeze et al., 2009; Alamu, and Mdaihli, ,1994). It is carried out within the closet of the compounds. They are mostly the fishermen's wives who are in purdah. Their main duty is to process the fish, which they normally buy from their husbands. The most popular method of fish processing used by the women within the fishing communities is by smoking using fuel wood. The techniques of smoking involve the use of traditional banda and iron pans made of cut drums. The implication of the traditional smoking banda in terms of high cost of fuel wood, time consuming, small quantity of fish smoked in a batch and low quality of smoked fish underscore NIFFR research effort in developing improved smoking banda in 1998.

The marketing activities of the women are limited to their village markets in their vicinities. According to Alamu, and Mdaihli, . (1994), women of child bearing age are disallowed from going out and the profit accruing is at the discretion of the husband, daughters and older women who have access to local fish markets. In addition, the major role of women in smallscale aquaculture activities most of the communities (New Bussa, Malale, Monai, Yuna and Tunga Mairuwa among others) around Kainji Lake Basin is noteworthy, considering that aquaculture has been recognized as an alternative to meet the increasing demand for fish of the growing population. They often perform most of the work of feeding and harvesting fish. The fish produced in these ponds are either eaten by the family or sold to purchase other foods.

\section{Important Issues about Gender and Fisheries}

The lack of adequate documentation on women's contribution in fisheries can be 
explained by the fact that production goals continue to dominate agendas of national government policy. Thus, research emphasis continues to be focused on the catching sector that is prominent among males rather than the processing and marketing sector that is dominated by female. Again, research is often 'gender-blind' and fails to see the broader perspective of livelihood issues. This is complicated by researchers who are often unable to include women in interviews and discussions for cultural reasons, or because they are persuaded that male family members are best placed to speak for them. Most often, gender data is aggregated with general fisheries data and there is no sexdisaggregated data, making it doubly difficult to extract information relevant to the gender relations in fisheries

The sexual division of work in the fisheries sector means that women are predominantly responsible for downstream activities, but they are rarely present in the main catching activity. However, declined fish catches observed on Kainji Lake and the worsening economic situation of fishing communities have implications for women in fishing activities.

\section{CONCLUSION}

Women play significant roles in all aspects of fisheries in Lake Kainji. Importantly, women's roles span reproduction and production. Women's reproductive roles are essential for nurturing and sustaining families and communities, and ensuring food security through fishing, food foraging, farming and related activities. The productive roles of women in fishing, processing and marketing the fish catch contribute significantly to household incomes and local economies.

\section{REFERENCES}

Aguilar, L, 2002. Fisheries and Aquaculture in Coastal Zones: Gender makes the
Difference. Geneva: IUCN Briefing Notes.

Alamu, S.O and Mdaihli, M.1994. Socioeconomic survey of women in artisanal fisheries in Kainji Lake Area: A case study of Wawu. Annual Report. National Institute for Freshwater Fisheries Research, New Bussa. Pp 190-194.

FAO 2004. Gender and food security. Fisheries. Available at http://www.fao/gender/en/fish-ehtm

Gillett, B. and G. Lightfoot, 2001, The economic importance of fisheries in the Pacific Islands: notes on the contribution of fisheries to GDP, employment, exports, and nutrition, Asian Development Bank (ADB), World Bank; Secretariat of the Pacific Community (SPC), Forum Fisheries Agency (FFA)

International Collective in Support of Fishworkers 1997. Women First: Report of the Women in Fisheries Programme of ICSF in India - vol. 1, Chennai: International Collective in Support of Fishworkers (Samudra Dossier, Women in Fisheries Series No. 2).

International Collective in Support of Fishworkers ICSF 2009 Women in Fisheries: Gender Relation in Fisheries. http:// www.icsf.net

International Collective in Support of Fishworkers. 2004. Gender agenda, women in fisheries: a collection of articles from SAMUDRA Report, Chennai, India. International Collective in Support of Fishworkers (SAMUDRA Dossier ) http://www.icsf.net/icsf2006/uploads /publications/dossier/pdf/english/issu e_58/ALL.pdf

Nwabeze, G.O., Ifejika, P.1, Erie, A.P, Ayanda, J.O and Wara, A. 2009. Influence of Socio-Economic 
Variables on Women Participation in Fisheries Activities around Kainji Lake Basin, Nigeria. Proceeding of Agricultural Extension Society of Nigeria, Held 2009, Federal University of Technology, Minna, Niger State. Pp. 118-124

Rettberg, S., Alamu, S.O and Mdaihli, M.1994. Fisherwomen of Kainji Lake. Annual Report. National Institute for Freshwater Fisheries Research, New Bussa. Pp 190-194.

UNDP (1995). United Nation Development Programme. Human Development Report, 1995.
Wara, A., Nwabeze, G.O., Tafida, A.A and Abubarka, S.M. 2007. Women in Fisheries: A Case Study of the Kainji Lake Basin, Nigeria. Proceeding of Fisheries Society of Nigeria, Held November, 2007, Birnin Kebbi, Kebbi State. Pp. 66-70.

Williams, S. B. 2006. The socio-economic potentials of women in riverine small-scale fisheries in Nigeria. $<$ Available from http//www.skk.uit.no> [Assessed $18^{\text {th }}$ July, 2006].

Yemaye, M 2010. Women in fisheries http://wif.icsf.net/icsf2006/jspFiles/w if/home.jsp 